\title{
THE EFFECT OF VOCABULARY MASTERY AND SENTENCE STRUCTURE ON READING COMPREHENSION OF ENGLISH EXPOSITION TEXTS
}

\author{
Hesty Utami Yunus ${ }^{1}$, \\ Supeno ${ }^{2}$, \\ Gustaman Saragih ${ }^{3}$, \\ Universitas Indraprasta PGRI \\ e-mail: hestyutamy@gmail.com ${ }^{1}$ \\ e-mail: supeno@unindra.ac.id ${ }^{2}$ \\ e-mail: gustaman_saragih@unindra.ac.id ${ }^{3}$
}

\begin{abstract}
Abstrak: Tujuan dari penelitian ini adalah untuk mengetahui: 1) Pengaruh penguasaan kosakata dan struktur kalimat secara bersama-sama terhadap pemahaman bacaan teks eksposisi bahasa Inggris. 2) Pengaruh penguasaan kosakata terhadap pemahaman bacaan teks eksposisi bahasa Inggris. 3) Pengaruh struktur kalimat terhadap pemahaman bacaan teks eksposisi bahasa Inggris. Metode dalam penelitian ini adalah survei. Populasi dalam penelitian ini adalah siswa kelas VIII SMP Swasta di Jakarta Timur dengan besar sampel sebanyak 90 siswa yang diambil secara acak dari siswa SMP Widya Manggala Jakarta Timur dan siswa SMP Kuntum Wijaya Kusuma Jakarta Timur. Penelitian dilaksanakan pada bulan September-November 2019. Instrumennya yaitu tes dan angket. Analisis dilakukan dengan metode regresi linear ganda. Hasil pengujian hipotesis diperoleh kesimpulan sebagai berikut: 1) Terdapat pengaruh yang signifikan penguasaan kosakata dan struktur kalimat secara bersama-sama terhadap pemahaman bacaan teks eksposisi bahasa Inggris siswa SMP Swasta di Jakarta Timur. Hal ini dibuktikan dengan perolehan nilai $\mathrm{Sig}=0,003<0,05$ dan $\mathrm{F}_{\text {hitung }}=6,382$. 2) Terdapat pengaruh yang signifikan penguasaan kosakata terhadap pemahaman bacaan teks eksposisi bahasa Inggris siswa SMP Swasta di Jakarta Timur. Hal ini dibuktikan dengan perolehan nilai Sig= 0,002 <0, 05 dan $\mathrm{t}_{\text {hitung }}=2,198$. 3) Terdapat pengaruh yang signifikan struktur kalimat terhadap pemahaman bacaan teks eksposisi bahasa Inggris siswa SMP Swasta di Jakarta Timur. Hal ini dibuktikan dengan perolehan nilai $\mathrm{Sig}=0,003<0,05$, dan oleh $\mathrm{t}_{\text {hitung }}=3,108$.
\end{abstract}

Kata Kunci: penguasaan kosakata, struktur kalimat, pemahaman bacaan teks eksposisi Bahasa Inggris.

\section{Pendahuluan}

Indonesia adalah salah satu negara yang kualitas pendidikannya masih sangat rendah jika dilihat dan dibandingkan dengan negara-negara berkembang lainnya. Meskipun perluasan untuk akses pendidikan sudah meningkat dengan cukup signifikan, namun masih banyak sekali yang menjadi tugas pemerintah dan guru dalam upaya mencanangkan program reformasi pendidikan yang akan membenahi kualitas dalam sektor pendidikan ini. Negara yang besar adalah negara yang memiliki kualitas pendidikan yang tinggi sehingga mampu menghasilkan manusia-manusia yang berkualitas yang memiliki daya saing tinggi dengan negara-negara lainnya. Negara yang maju adalah negara yang memiliki kapasitas yang besar dalam memajukan pembangunan dan kesejahteraan semua kalangan masyarakat. Oleh sebab itu kita sangat membutuhkan pendidikan yang sama rata dan layak untuk didapatkan semua kalangan masyarakat, pendidikan yang memiliki sistem yang tidak kalah bagus dari negara lain.

Seiring dengan perkembangan zaman, pendidikan juga akan semakin maju dan berkembang, tetapi dengan seiring perkembangan pengetahuan maka akan mulai memunculkan satu persatu persoalan yang 


\section{INFERENCE: Journal of English Language Teaching}

Vol. 4, No. 3, December 2021 - March 2022

p-ISSN: 2615-8671

e-ISSN: 2615-868X

baru dalam bidang pendidikan. Di sinilah peran seorang guru sangat dibutuhkan dalam mengelola setiap informasi baru yang diterimanya untuk diteliti dan diterapkan dalam dunia pendidikan di Indonesia. Beragam permasalahan dapat memunculkan ide-ide kreatif dari seorang guru untuk mengetahui setiap kebutuhan setiap siswa dan tentunya dengan berpegang pada aturan-aturan yang berlaku.

Guru adalah salah satu penentu terbesar dalam mendidik dan melatih manusia dari generasi ke generasi yang kelak akan berperan penting dalam pertumbuhan ekonomi dan sosial masyarakat. Guru harus memilih-milih metode yang paling cocok digunakan untuk lebih memaksimalkan potensi atau kemampuan siswa dalam belajar. Selebihnya para siswa akan dituntut untuk lebih giat dalam belajar dan mengembangkan pengetahuannya bahkan belajar akan menjadi kebutuhan pokok yang harus terpenuhi. Siswa juga dapat belajar dan membaca informasi-informasi yang beragam dari media-media yang ada sekarang ini untuk memperluas pengetahuan mereka. Membaca tidak dapat dipisahkan dari kehidupan manusia. Dengan membaca kita dapat mengetahui banyak hal salah satunya adalah ilmu pengetahuan. Oleh sebab itu, kegiatan membaca menjadi kegiatan yang sangat penting yang dilakukan oleh manusia terutama pelajar.

Siswa SD sampai dengan siswa SMA melakukan kegiatan membaca. Dalam hal ini adalah membaca teks bahasa Inggris, menjadi kegiatan yang sering dikatakan membosankan bagi siswa manakala belum bisa dimengerti dan dipahami maknanya. Membaca dalam pembelajaran bahasa asing merupakan salah satu kegiatan yang memiliki intensitas yang tinggi dalam pembelajaran bahasa Inggris. Melalui kegiatan membaca, siswa diharapkan tidak hanya memperoleh dan memahami informasi atau pesan yang disampaikan penulis, akan tetapi juga memperoleh gambaran penerapan bahasa Inggris secara tertulis. Mengusai bahasa Inggris dengan baik akan mempermudah siswa memahami mata pelajaran yang lain, karena itu bahasa Inggris merupakan penunjang untuk mata pelajaran yang lain.

Proses belajar membaca teks bahasa Inggris di Indonesia tentunya tidak semudah proses membaca teks bahasa Indonesia. Selain ejaan yang berbeda dengan pelafalannya, pembelajaran membaca teks berbahasa Inggris diawali dengan pembelajaran kata, frasa, wacana dengan kosakata yang mudah ke wacana yang lebih sulit dan dari wacana pendek dan sederhana ke wacana yang lebih panjang. Di dalam wacana yang lebih panjang mengandung kosakata, struktur kalimat, struktur paragraf, tata bahasa, unsur bahasa, kata ganti, dan rujukan kata yang harus dapat dipahami oleh setiap pembacanya. Setiap tahapan dalam proses pembelajaran membaca dalam bahasa Inggris akan menentukan tingkat pemahaman siswa atas teks yang dibacanya.

Untuk memahami suatu teks bahasa Inggris kita harus menguasai salah satunya adalah kosakata, namun banyak siswa yang belum menguasai kosakata di antaranya disebabkan malasnya membuka kamus dan menghafal kosakata (Kartono, 2018; Manullang \& Supeno, 2020). Penguasaan kosakata pada prinsipnya merupakan pemahaman atau kesanggupan menggunakan kata-kata di dalam keterampilan berbahasa baik secara lisan maupun tulisan. Dengan demikian kosakata memegang peranan yang sangat penting dalam pengajaran bahasa Inggris, dan untuk meningkatkan kecerdasan seseorang. Penguasaan kosakata sangat penting untuk membantu memahami teks bahasa Inggris (Faliyanti, 2015; Fitriani \& Suendarti, 2021). Siswa yang baik dituntut untuk memiliki pengetahuan tentang kosakata yang luas sehingga dengan mudah dapat memahami arti atau makna dari suatu kalimat dalam bahasa Inggris (Novianti, 2019; Tarigan, 2011).

Struktur kalimat dalam sebuah teks juga sangat penting. Sebuah teks dapat dikenali jenisnya dengan cara melihat struktur teks. Begitu pun yang terjadi pada sebuah teks eksposisi yang memiliki struktur khas yang menjadi pembeda dengan jenis teks lainnya. Struktur ini sangat penting karena bertanggung jawab untuk membentuk sebuah teks menjadi eksposisi.

Tujuan yang diharapkan dalam pembelajaran menyusun teks eksposisi adalah agar siswa mampu menyusun teks eksposisi dengan tepat. Teks eksposisi yang dimaksud adalah teks eksposisi yang sesuai dengan struktur teks dan unsur kebahasaan (ejaan, diksi, dan kalimat) yang tepat yakni di dalamnya terdapat bagaimana seorang penulis mengemukakan pendapatnya tentang suatu objek atau uraian dari sebuah topik dengan memberikan argumentasi berupa penguatan atau suatu alasan yang dikemukakan oleh penulis untuk mempertahankan pendapatnya dalam suatu teks eksposisi serta memberikan penegasan ulang yang dilakukan oleh penulis dalam tulisannya untuk menguatkan argumen.

Bacaan teks eksposisi sebagai salah satu hasil belajar tentunya mengandung struktur kalimat dan unsur kebahasaan sebagai pembeda dari satu teks dengan teks lainnya. Kosakata dan struktur kalimat ini biasa digunakan dalam kehidupan sehari-hari siswa. Kedua hal ini mungkin akan sangat mudah dipahami 
siswa ketika membaca teks berbahasa Indonesia, karena bahasa Indonesia merupakan bahasa ibu yang selalu mereka lakukan untuk berkomunikasi dengan orang-orang di lingkungannya. Sedangkan jika teksnya berbahasa Inggris, para siswa memerlukan usaha yang lebih dalam memahami isi dari teks tersebut. Sehingga cukup banyak yang mengalami kendala dalam hal tersebut. Kesulitan kosakata menjadi faktor sulitnya siswa dalam memahami teks bacaan. Guru harus sadar betul bahwa membaca merupakan sesuatu yang harus diajarkan dan dibiasakan bagi siswanya. Materi pembelajaran mengenai bacaan berbahasa Inggris sangat membutuhkan keterampilan guru dalam mengemas bacaan tersebut agar terlihat lebih menarik untuk dibaca dan tujuannya dapat tersampaikan dengan baik kepada siswa.

\section{Pengertian Penguasaan Kosakata}

Tujuan dari sebuah pembelajaran khususnya pembelajaran bahasa adalah untuk memberi siswa pengetahuan baru dan keterampilan baru yang belum mereka miliki. Namun demikian, siswa harus memahami setiap materi pembelajaran yang diberikan oleh guru, agar siswa dapat dengan mudah menguasai pembelajaran tersebut. Allen (2000) mengatakan bahwa, "mastery is the skill or knowledge that makes one master of a subject". Sebelum guru mengajarkan suatu materi kepada muridnya, penguasaan suatu materi sangat diperlukan dan akan sangat membantu dalam proses pembelajaran. Seorang guru yang belum menguasai sepenuhnya materi yang diberikan kepada siswa tidak bisa menjelaskan materi dengan baik dan benar. Hal ini yang akan membuat para siswa bingung dan tidak bisa menjawab soal-soal yang diberikan. Oleh sebab itu penguasaan suatu materi haruslah kepada setiap guru sebelum melakukan kegiatan pembelajaran agar guru dapat menjawab setiap pertanyaan yang diajukan oleh siswa mengenai materi pembelajaran dengan tepat dan benar sesuai kurikulum yang berlaku.

Harmer (2020, hal. 13; Harmer, 2007) mengatakan bahwa "mastery is the skill or knowledge of master" yang maksudnya adalah suatu kemampuan atau keahlian seseorang ketika dia mampu menguasai suatu bidang ilmu pengetahuan. Jika berbicara tentang keahlian seseorang, kita pasti akan langsung memikirkan tentang tingkat penguasaan seseorang terhadap bidang atau ilmu yang dia tekuni dan pelajari dalam jangka waktu tertentu. Artinya hanya seseorang yang ahli dan benar-benar menguasai bidangnyalah yang dapat mengajar orang yang belum memahami bidang tersebut.

Porter \& Hernacki (2003, hal. 953) mengatakan bahwa, "Mastery is learning or understanding something completely and having no difficulty in using it". Berdasarkan teori tersebut, guru memang diharuskan untuk mendalami dan memahami secara keseluruhan materi yang ingin diajarkan sebelum memulai proses belajar mengajar di kelas. Hal ini sangat penting karena melihat siswa itu akan terus mengembangkan pengetahuannya, berpikir kritis dan mengingat pembelajaran yang dibawakan oleh guru mata pelajarannya maka guru haruslah berhati-hati dalam membawakan suatu pembelajaran. Jadi yang paling penting disini adalah tingkat penguasaan materi yang dimiliki seorang guru untuk mengajarkan ilmu di bidangnya.

Wiggins (2014, hal. 14) mmengatakan bahwa, "mastery is affective transfer of learning in authentic and worthy performance". Seseorang harus menguasai suatu bidang ilmu pengetahuan dan bahkan kreatif dalam menggunakan pengetahuan tersebut serta memahami kunci dalam pemilihan konteks dalam ilmu pengetahuan. Ini dapat dilihat dari teori yang ada bahwa penguasaan adalah sebuah bagian yang penting dalam suatu proses pembelajaran bahasa. Berdasarkan teori dan pendapat di atas, dapat disimpulkan bahwa penguasaan berkaitan erat dengan tingkat pemahaman dan keterampilan seseorang dalam mengajarkan suatu ilmu di bidang tertentu sehingga target atau tujuan pembelajarannya tercapai atau terpenuhi.

\section{Pengertian Struktur Kalimat}

Struktur kalimat merupakan suatu aspek yang sangat penting dalam belajar bahasa Inggris. Hal ini yang sering kali di anggap siswa sebagai pelajaran yang membosankan dan sulit untuk dipelajari. Struktur kalimat sangat penting di pelajari karena sangat erat kaitannya dengan keterampilan berbicara dan menulis agar siswa dapat berkomunikasi secara jelas, baik secara lisan maupun tulisan dalam bahasa Inggris . Grammar menentukan bagaimana kata-kata disusun dalam membentuk unit-unit bahasa yang mempunyai makna tertentu. Thornbury (2007, hal. 1) mengatakan bahwa, "Grammar is partlty the study what forms for structure are possible in language". Jadi grammar itu lebih menekankan pada pembelajaran tentang struktur kalimat atau susunan dan aturan-aturan dalam mengatur dan menata penggunaan bahasa sehingga bahasa yang digunakan menjadi bahasa yang dimengerti dan dipahami oleh pendengar. Struktur kalimat 
sebagai jembatan untuk menyampaikan bahasa sebagai suatu makna yang jelas dan teratur, itulah mengapa grammar atau struktur kalimat itu sangat penting dalam pembelajaran bahasa. Cameron (2001, hal. 98) mengatakan bahwa, "Grammar is necessary to express precise meanings in discourse, and ties closely into vocabulary learning and using the foreign language, and that grammar learning can evolve from the learning of chunks of language".

Setiap bahasa memiliki pengaturan struktur bahasa yang berbeda-beda dan semuanya dapat berevolusi sesuai dengan perkembangan yang ada. Jadi grammar tidak dapat dihilangkan dari suatu pembelajaran bahasa karena grammar sangat erat kaitannya dengan pembelajaran kosakata khususnya dalam pembelajaran bahasa asing. Dykes (2007, hal. 5) mengatakan bahwa, "Grammar is a language to talk about language". Hal ini dapat diartikan bahwa grammar adalah bahasa untuk mempelajari bahasa. Karena dari grammar, siswa bisa mempelajari bagaimana berkomunikasi dengan bahasa tidak lepas kaitannya dengan mempelajari grammar; dimulai dari kosakata dan fungsinya, pola kalimat, ungkapan, dan makna. Dari beberapa teori dan pendapat di atas maka dapat disimpulkan bahwa struktur kalimat atau grammar adalah suatu bahasa adalah kumpulan aturan yang mengatur setiap susunan dari kalimat dan lebih menekankan pada pembelajaran tentang struktur kalimat atau susunan maupun aturan-aturan dalam mengatur dan menata penggunaan Bahasa. Struktur kalimat atau grammar pada setiap bahasa juga dapat berevolusi sedikit demi sedikit seiring dengan perkembangan zaman.

\section{Pengertian Pemahaman Bacaan Teks Eksposisi Bahasa Inggris}

Pemahaman didefinisikan proses berpikir dan belajar. Dikatakan demikian karena untuk menuju ke arah pemahaman perlu di ikuti dengan belajar dan berpikir. Pemahaman merupakan proses, perbuatan dan cara memahami. Dalam Taksonomi Bloom , pemahaman adalah kesanggupan memahami setingkat lebih tinggi dari pengetahuan. Namun, tidaklah berarti bahwa pengetahuan tidak dipertanyakan sebab untuk dapat memahami, perlu terlebih dahulu mengetahui atau mengenal. Longstreet \& Shane (1992, hal. 183) mengatakan bahwa "comprehension is the process of building a connection between what the reader knows and what he or she doesn't know, between the new and the old". Jadi tingkat pemahaman seseorang itu dapat di ukur dari seberapa besar kapasitas seseorang dalam mencapai tingkat pengetahuan yang lebih tinggi dari yang dia ketahui sebelumnya. Dengan kata lain otak secara otomatis mengingat pengetahuan yang diperoleh sebelumnya dan menjadikanya alat untuk menambah wawasan dengan tujuan mempermudah seseorang memahami suatu pembelajaran. Johnson \& Johnson (2013) mengatakan bahwa pemahaman dalam belajar merupakan hasil dari proses penalaran, evaluasi, dan memanfaatkan informasi yang ada. Jadi pemahaman itu seperti mengingat kembali apa yang telah dipelajari dan mengevaluasi atau mengingatnya kembali sebagai sarana untuk memanfaatkan atau menggali setiap informasi yang diperoleh oleh otak seseorang guna dijadikan penunjang untuk memahami pengetahuan yang baru.

Pemahaman yang luas tentang suatu materi pembelajaran sangat berguna dalam proses pembelajaran (Johnson \& Johnson, 2013), tetapi untuk menerapkan semuanya itu diperlukan penguasaan materi tersebut sehingga dapat dengan mudah menerapkannya. khususnya dalam pembelajaran bahasa Inggris. seorang siswa yang ingin mempraktikkan pengucapan bahasa Inggris haruslah memahami arti, struktur kalimat yang diucapkan, dan pelafalannya. Setelah memahami semua tahapan-tahapan tersebut, siswa akan mempraktikkan secara berulang-ulang dan dengan demikian siswa akan menguasai bahasa Inggris dengan mudah. Smith (2001:27) mengatakan bahwa, "comprehension is the capability to understand or grasp it ideas of one passage". Pemahaman juga dapat di artikan sebagai kemampuan atau bakat alami dari seseorang untuk mampu mengenal, menelaah dan menyaring setiap informasi yang di dapatkan sehingga mampu dengan mudah menangkap atau memahami apa yang di ucapkan oleh pembicara atau guru. Jadi kesimpulan dari pengertian pemahaman adalah proses berpikir dan belajar dari seseorang dengan mengenal, menelaah dan menyaring setiap informasi yang di dapatkan dan akan digunakan otak sebagai penunjang untuk memahami setiap pengetahuan yang baru didapatkan.

\section{Metode}

Metode yang digunakan dalam penelitian ini adalah penelitian survei. Penelitian survei adalah penelitian yang dilakukan pada populasi besar maupun kecil, tetapi data yang dipelajari adalah data yang diambil dari sampel populasi tersebut, sehingga ditemukan kejadian-kejadian relatif, distribusi dan hubungan antara variabel (Sugiyono, 2016, 2017). Metode survei yang akan digunakan pada penelitian ini 
disertai dengan teknik korelasional melalui pendekatan Pearson Correlation Product Moment. Adapun syarat-syarat yang harus dipenuhi dalam menggunakan korelasi Pearson adalah: 1. Pengambilan sampel dari target populasi harus random 2. Data yang dikumpulkan harus berkala interval atau rasio 3. Variasi skor dari kedua variabel harus sama 4. Distribusi skor variabel harus berupa distribusi normal 5. Hubungan antara variabel $\mathrm{X}$ dan $\mathrm{Y}$ bersifat linier. Variabel penelitian ini terdiri dari variabel terikat, yaitu keterampilan membaca Teks Eksposisi bahasa Inggris ( $\mathrm{Y})$ dan dua variabel bebas, yaitu Penguasaan Kosakata $\left(\mathrm{X}_{1}\right)$, dan Penguasaan Struktur Paragraf $\left(\mathrm{X}_{2}\right)$, maka model korelasi hubungan antar variabel dalam penelitian ini adalah sebagai berikut;

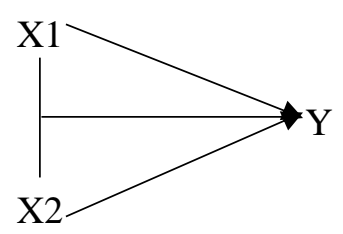

Gambar 1. Konstelasi Hubunga Antar Variabel Penelitian

Keterangan:

$\mathrm{X} 1 \quad$ :Penguasaan kosakata

$\mathrm{X} 2$ :Penguasaan struktur paragraf teks eksposisi

Y :Pemahaman bacaan teks eksposisi bahasa Inggris

Survei pada penelitian ini menggunakan analisis regresi linear berganda, yaitu untuk mencari:

1. Pengaruh penguasaan kosakata dan struktur kalimat secara bersama-sama terhadap pemahaman bacaan teks eksposisi bahasa Inggris.

2. Pengaruh penguasaan kosakata terhadap pemahaman bacaan teks eksposisi bahasa Inggris.

Pengaruh struktur kalimat terhadap pemahaman bacaan teks eksposisi bahasa Inggris.

\section{Hasil dan Diskusi}

Data Pemahaman Bacaan Teks Eksposisi bahasa Inggris diperoleh dari nilai tes tulis sebanyak 90 siswa yang menjadi sampel penelitian. Nilai yang diperoleh adalah terendah 9 , tertinggi 28 , rata-rata sebesar 19,84 median sebesar 20,00, modus sebesar 16 dan simpangan baku sebesar 4,324.

\section{Tabel 1. Deskripsi Data Penelitian Pemahaman Bacaan Teks Eksposisi Bahasa Inggris}

\begin{tabular}{|c|c|c|}
\hline \multicolumn{3}{|l|}{ Statistics } \\
\hline \multicolumn{3}{|c|}{ Pemahaman Bacaan Teks Eksposisi Bahasa Inggris } \\
\hline \multirow{2}{*}{$\mathrm{N}$} & Valid & 90 \\
\hline & Missing & 0 \\
\hline \multicolumn{2}{|c|}{ Mean } & 19,84 \\
\hline \multicolumn{2}{|c|}{ Median } & 20,00 \\
\hline \multicolumn{2}{|c|}{ Mode } & 16 \\
\hline \multicolumn{2}{|c|}{ Std. Deviation } & 4,324 \\
\hline \multicolumn{2}{|c|}{ Minimum } & 9 \\
\hline \multicolumn{2}{|c|}{ Maximum } & 28 \\
\hline
\end{tabular}

Bila dilihat dari hasil perhitungan di atas, maka bisa dikatakan bahwa prestasi belajar bahasa Inggris siswa SMP Swasta di Jakarta Timur bersifat homogen. Hal ini diindikasikan dengan perolehan nilai rata-rata sebesar 19,84. Untuk memperjelas data di atas, digambarkan dalam histogram sebagai berikut: 


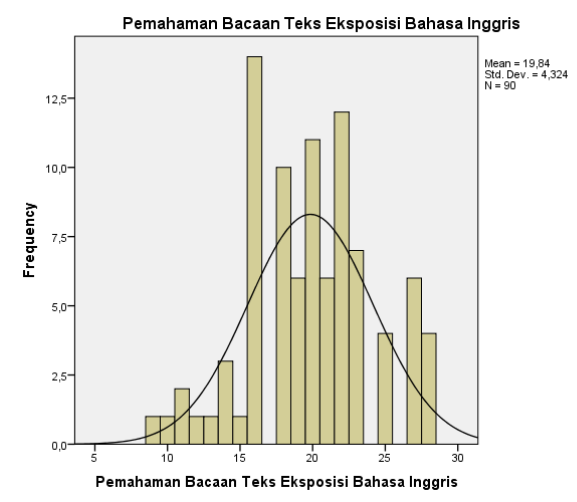

\section{Gambar 2. Histogram Poligon Variabel Pemahaman Bacaan Teks Eksposisi Bahasa Inggris}

Dari histogram dan poligon frekuensi di atas dapat disimpulkan bahwa data pemahaman bacaan teks eksposisi bahasa Inggris siswa SMP Swasta di Jakarta Timur memiliki distribusi normal.

Data minat baca diperoleh dari kuesioner yang dijawab oleh 90 siswa sebagai responden dihasilkan nilai terendah 9, skor tertinggi 32, skor rata-rata sebesar 20,20, median sebesar 20,00, modus sebesar 20 dan simpangan baku sebesar 5,401.

\section{Tabel 2. Deskripsi data Penelitian Penguasaan Kosakata}

\begin{tabular}{|c|c|c|}
\hline \multicolumn{3}{|c|}{ Statistics } \\
\hline \multicolumn{3}{|c|}{ Penguasaan Kosakata } \\
\hline \multirow{2}{*}{$\mathrm{N}$} & Valid & 90 \\
\hline & Missing & 0 \\
\hline \multicolumn{2}{|l|}{ Mean } & 20,20 \\
\hline \multicolumn{2}{|l|}{ Median } & 20,00 \\
\hline \multicolumn{2}{|l|}{ Mode } & 20 \\
\hline \multicolumn{2}{|c|}{ Std. Deviation } & 5,401 \\
\hline \multicolumn{2}{|c|}{ Minimum } & 9 \\
\hline \multicolumn{2}{|c|}{ Maximum } & 32 \\
\hline
\end{tabular}

Dari hasil perhitungan di atas, maka bisa dikatakan bahwa penguasaan kosakata siswa SMP Swasta di Jakarta Timur bersifat homogen. Hal ini diindikasikan dengan perolehan nilai rata-rata skor 20,20 mendekati skor mediannya. Untuk memperjelas data di atas, digambarkan dalam histogram sebagai berikut:

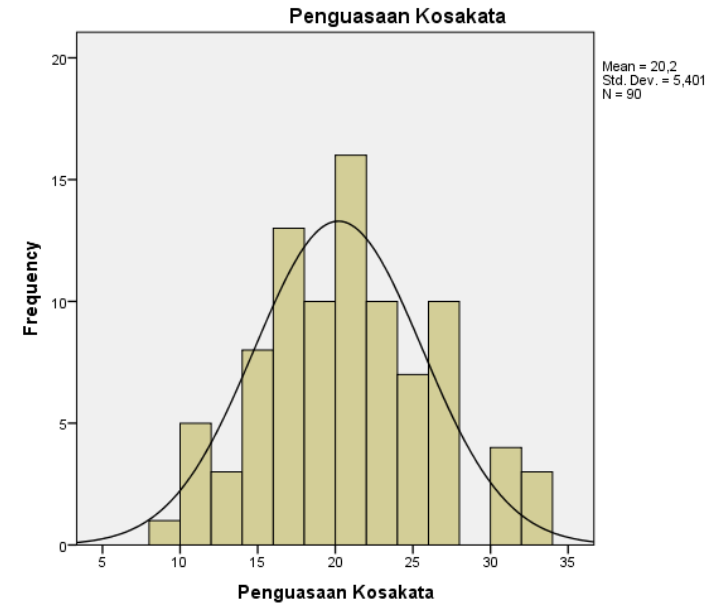




\section{Gambar 3. Histogram Poligon Variabel Penguasaan Kosakata}

Dari histogram dan poligon frekuensi di atas dapat disimpulkan bahwa penguasaan kosakata siswa SMP Swasta di Jakarta Timur memiliki sebaran yang normal.

Data struktur kalimat diperoleh dari hasil tes yang dijawab oleh 90 siswa dihasilkan skor terendah 8 , skor tertinggi 29 , skor rata-rata sebesar 18,54 , median 19,00 , modus sebesar 20 , dan simpangan baku sebesar 3,808 .

\begin{tabular}{|c|c|c|}
\hline \multicolumn{3}{|l|}{ Statistics } \\
\hline \multicolumn{3}{|c|}{ Struktur Kalimat } \\
\hline & Valid & 90 \\
\hline N & Missing & 0 \\
\hline Mean & & 18,54 \\
\hline Median & & 19,00 \\
\hline Mode & & 20 \\
\hline Std. Devi & & 3,808 \\
\hline Minimum & & 8 \\
\hline Maximum & & 29 \\
\hline
\end{tabular}

Dari hasil perhitungan di atas, maka dapat dikatakan bahwa data struktur kalimat siswa SMP Swasta di Jakarta Timur bersifat homogen. Hal ini diindikasikan dengan perolehan skor rata-rata sebesar 18,54 mendekati nilai mediannya. Untuk memperjelas data di atas, digambarkan dalam histogram sebagai berikut :

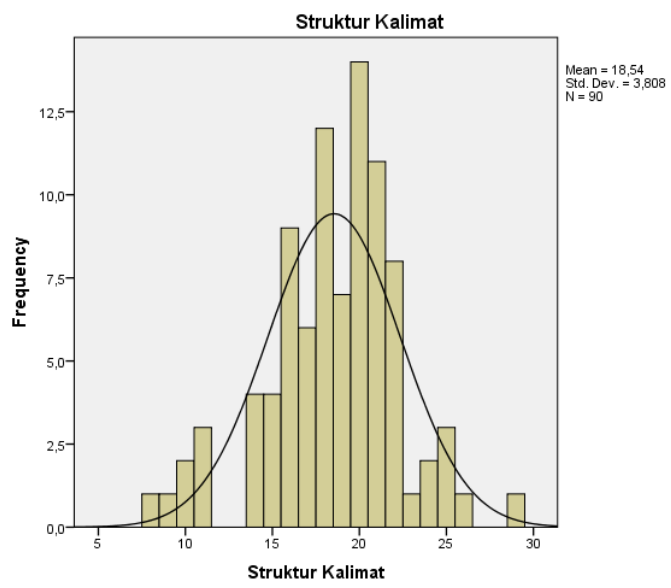

\section{Gambar 4. Histogram Poligon Variabel Struktur Kalimat}

Dari histogram dan poligon frekuensi di atas dapat disimpulkan bahwa data struktur kalimat siswa SMP Swasta di Jakarta Timur memiliki sebaran yang normal.

\section{Uji Persyaratan Analisis Regresi}

1. Uji Asumsi Klasik

a. Uji Normalitas Data

Persyaratan regresi yang baik jika data penelitian mengikuti distribusi normal. 
INFERENCE: Journal of English Language Teaching

Vol. 4, No. 3, December 2021 - March 2022

p-ISSN: 2615-8671

e-ISSN: 2615-868X

Tabel 4.Uji Normalitas Data

One-Sample Kolmogorov-Smirnov Test

\begin{tabular}{|c|c|c|c|c|}
\hline & & $\begin{array}{c}\text { Penguasaan } \\
\text { Kosakata }\end{array}$ & Struktur Kalimat & $\begin{array}{c}\text { Pemahaman } \\
\text { Bacaan Teks } \\
\text { Eksposisi } \\
\text { Bahasa Inggris }\end{array}$ \\
\hline $\mathrm{N}$ & & 90 & 90 & 90 \\
\hline \multirow[t]{2}{*}{ Normal Parameters ${ }^{a, b}$} & Mean & 20,20 & 18,54 & 19,84 \\
\hline & Std. Deviation & 5,401 & 3,808 & 4,324 \\
\hline \multirow[t]{3}{*}{ Most Extreme Differences } & Absolute &, 070 & 110 &, 080 \\
\hline & Positive &, 070 & ,093 &, 080 \\
\hline & Negative &,- 057 &,- 110 &,- 076 \\
\hline Test Statistic & &, 070 & 110 &, 080 \\
\hline Asymp. Sig. (2-tailed) & &, $840^{c, d}$ & $288^{\circ}$ & $686^{\mathrm{c} d \mathrm{~d}}$ \\
\hline
\end{tabular}

Dari tabel di atas menunjukkan bahwa uji hipotesis yang menyatakan distribusi data pada analisis regresi ini mengikuti distribusi normal. Hal ini ditunjukkan dengan semua nilai Asymp. Sig > 0,05. Hal ini berarti semua data berdistribusi normal.

\section{b. Uji Multikolinearitas}

Uji multikolinieritas bertujuan untuk menguji apakah model regresi ditemukan adanya korelasi yang sempurna antar variabel bebas (independent). Model regresi yang baik seharusnya tidak terjadi korelasi yang sempurna diantara variabel bebas. Salah satu cara untuk untuk mendeteksi adanya multikolinieritas adalah dengan melihat tolerance atau Varian Inflation Factor (VIF). Jika tolerance lebih kecil dari 0,1 atau nilai VIF diatas 10 maka terjadi multikolinearitas. Aturan yang berikutnya adalah jika nilai Tol dan VIF mendekati angka 1 maka dalam analisis regresi ganda tidak ada multikolinearitas.

Tabel 5. Uji Multikolinearitas

\begin{tabular}{|c|c|c|c|c|c|c|c|c|c|c|c|}
\hline \multicolumn{12}{|c|}{ Coefficients $^{\mathrm{s}}$} \\
\hline \multirow[b]{2}{*}{ Mode } & & \multicolumn{2}{|c|}{ Unstandardized Coefficients } & $\begin{array}{c}\text { Standardized } \\
\text { Coefficients }\end{array}$ & \multirow[b]{2}{*}{ t } & \multirow[b]{2}{*}{ Sig. } & \multicolumn{3}{|c|}{ Correlations } & \multicolumn{2}{|c|}{ Collinearity Statistics } \\
\hline & & $\mathrm{B}$ & Std. Error & Beta & & & Zero-order & Partial & Part & Tolerance & VIF \\
\hline 1 & (Constant) & 11,461 & 2,444 & & 4,689 & .000 & & & & & \\
\hline & Penguasaan Kosakata & .081 & .082 & 102 & .889 & .328 & .176 & 105 & .099 & .846 & 1,058 \\
\hline & Struktur Kalimat & .303 & .117 & .320 & 3,108 & .003 & .344 & .316 & .311 & .846 & 1,058 \\
\hline
\end{tabular}

Hasil uji multikolininearitas pada tabel di atas diketahui bahwa hasil Tolerance 0, 946>0,1 atau varian inflation factor (VIF) $1,058<10$. Sehingga dapat dinyatakan bahwa tidak ada multikolinearitas antara penguasaan kosakata dan struktur kalimat pada analisis regresi ganda ini.

\section{c. Uji Heteroskedastisitas}

Heteroskedastisitas adalah apabila kesalahan atau residual yang diamati tidak memiliki varian yang konstan. Kondisi heteroskedastisitas sering terjadi pada data cross section, atau data yang diambil dari beberapa responden pada suatu waktu tertentu.

Salah satu metode untuk mendeteksi adanya heteroskedastisitas adalah dengan membuat scatterplot antara Standardized Residual (ZRESID) dan Standardized Predicted Value (Y topi). Pada gambar di bawah ini menunjukkan tidak ada perubahan e sepanjang $\mathrm{Y}$ topi, maka dinyatakan tidak ada heteroskedastisitas pada galat (error/residual) tersebut. 
Scatterplot

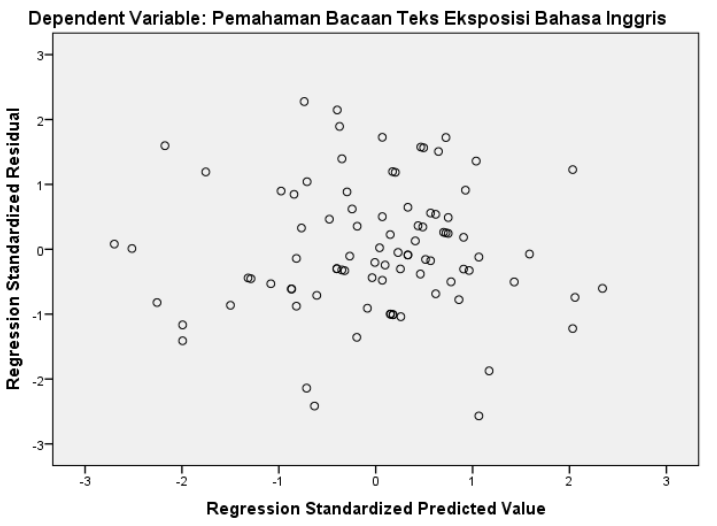

Gambar 5. Scatterplot Uji Heteroskedastisitas

Dari gambar di atas menunjukkan bahwa titik-titik menyebar secara acak dan tidak membentuk pola tertentu yang jelas, serta tersebar di atas maupun di bawah angka 0 pada sumbu Y. Hal ini menunjukkan bahwa tidak terjadi heteroskedastisitas pada model regresi tersebut, sehingga dapat dipakai untuk memprediksi variabel pemahaman bacaan teks eksposisi bahasa Inggris berdasarkan penguasaan kosakata dan struktur kalimat.

\section{d. . Uji Linearitas}

Uji lineritas dilakukan untuk menentukan teknik dalam analisis regresi apakah variabel bebas $\left(\mathrm{X}_{1}\right.$ dan $\mathrm{X}_{2}$ ) dan variabel terikat $(\mathrm{Y})$ terbentuk linear. Uji linearitas ini menggunakan perhitungan SPSS 20.0

i. Linieritas Regresi Pengaruh Variable $\mathrm{X}_{1}$ atas $\mathrm{Y}$

Hasil uji linearitas regresi antara penguasaan kosakata dengan pemahaman bacaan teks eksposisi bahasa Inggris, perhitungan SPSS 22.0 sebagai berikut:

Tabel 5. Hasil Pengujian Linearitas Regresi Variabel $X_{1}$ atas $Y$

ANOVA Table

\begin{tabular}{|c|c|c|c|c|c|c|c|}
\hline & & & $\begin{array}{l}\text { Sum of } \\
\text { Squares } \\
\end{array}$ & df & $\begin{array}{l}\text { Mean } \\
\text { Square } \\
\end{array}$ & $\mathrm{F}$ & Sig. \\
\hline \multirow{5}{*}{$\begin{array}{l}\text { Pemahaman Bacaan Teks } \\
\text { Eksposisi Bahasa Inggris * } \\
\text { Penguasaan Kosakata }\end{array}$} & \multirow[t]{3}{*}{ Between Groups } & (Combined) & 453,869 & 20 & 22,693 & 1,294 & .213 \\
\hline & & Linesrity & 51,819 & 1 & 51,819 & 2,965 & .090 \\
\hline & & $\begin{array}{l}\text { Deviation from } \\
\text { Linearity }\end{array}$ & 402,050 & 19 & 21,181 & 1,207 & .278 \\
\hline & \multicolumn{2}{|l|}{ Within Groups } & 1209,954 & 69 & 17,536 & & \\
\hline & \multicolumn{2}{|l|}{ Total } & 1683,822 & 89 & & & \\
\hline
\end{tabular}

Berdasarkan hasil perhitungan di atas diperoleh hasil perhitungan Deviation from Linearity dengan Fo $=1,207$ dan Sig. $=0,278>0,05$. Hal ini memiliki pengertian bahwa variabel penguasaan kosakata dengan pemahaman bacaan teks eksposisi bahasa Inggris siswa mempunyai hubungan yang linear.

ii. Linieritas Regresi Pengaruh Variabel $\mathrm{X}_{2}$ atas $\mathrm{Y}$

Hasil uji linearitas regresi antara struktur kalimat dengan pemahaman bacaan teks eksposisi bahasa Inggris dengan perhitungan SPSS 22.0 sebagai berikut: 
INFERENCE: Journal of English Language Teaching

Vol. 4, No. 3, December 2021 - March 2022

p-ISSN: 2615-8671

e-ISSN: 2615-868X

Tabel 6. Hasil Pengujian Linearitas Regresi Variabel $Y$ atas $\mathbf{X}_{2}$

\begin{tabular}{|c|c|c|c|c|c|c|c|}
\hline \multicolumn{8}{|c|}{ ANOVA Table } \\
\hline & & & $\begin{array}{l}\text { Sum of } \\
\text { Squares }\end{array}$ & df & Mean Square & $\mathrm{F}$ & Sig. \\
\hline \multirow{5}{*}{$\begin{array}{l}\text { Prestasi Belajar Bahasa } \\
\text { Inggris * Penguasaan } \\
\text { Kosakata }\end{array}$} & Between Groups & (Combined) & 1188,397 & 9 & 132,044 & 15,756 &, 000 \\
\hline & & Linearity & 970,444 & 1 & 970,444 & 115,797 &, 000 \\
\hline & & Deviation from Linearity & 217,952 & 8 & 27,244 & 3,251 &, 006 \\
\hline & Within Groups & & 335,223 & 40 & 8,381 & & \\
\hline & Total & & 1523,620 & 49 & & & \\
\hline
\end{tabular}

Berdasarkan hasil perhitungan di atas diperoleh hasil Deviation from Linearity dengan $\mathrm{Fo}=3,251$ dan Sig. $=0,006<0,05$. Hal ini memiliki pengertian bahwa variabel penguasaan kosakata dengan prestasi belajar bahasa Inggris siswa mempunyai hubungan yang linear.

\section{Pengujian Hipotesis}

Pengajuan hipotesis dilakukan sesuai dengan ketentuan yang telah dijelaskan dalam Bab III. Hasil perhitungan dan pengujian bisa dilihat pada tabel di bawah ini:

Tabel 7. Hasil Perhitungan Pengujian Koefisien Korelasi Ganda Variabel $X_{1}$ dan $X_{2}$ terhadap $Y$

\begin{tabular}{|rl|r|r|r|r|r|}
\hline \multicolumn{1}{|l|}{ ANOVA $^{\mathrm{a}}$} \\
\hline 1 & Sum of Squares & \multicolumn{1}{c|}{ df } & Mean Square & \multicolumn{1}{c|}{ F } & Sig. \\
\hline & Regression & 212,871 & 2 & 106,435 & 6,382 & $0^{\circ}$ \\
& Residual & 1450,951 & 87 & 16,678 & & \\
& Total & 1663,822 & 89 & & & \\
\hline
\end{tabular}

a. Dependent Variable: Pemahaman Bacaan Teks Eksposisi Bahasa Inggris

b. Predictors: (Constant), Struktur Kalimat, Penguasaan Kosakata

Tabel 8. Hasil Perhitungan Pengujian Signifikansi Koefisien Regresi Variabel $X_{1}$ dan $X_{2}$ terhadap Y

\begin{tabular}{|c|c|c|c|c|c|c|}
\hline \multicolumn{7}{|c|}{ Coefficients $^{a}$} \\
\hline \multirow{2}{*}{\multicolumn{2}{|c|}{ Model }} & \multicolumn{2}{|c|}{ Unstandardized Coefficients } & \multirow{2}{*}{$\begin{array}{c}\begin{array}{c}\text { Standardized } \\
\text { Coefficients }\end{array} \\
\text { Beta } \\
\end{array}$} & \multirow[b]{2}{*}{$\mathrm{t}$} & \multirow[b]{2}{*}{ Sig. } \\
\hline & & $\mathrm{B}$ & Std. Error & & & \\
\hline \multirow[t]{3}{*}{1} & (Constant) & 1,461 & 2,444 & & 4,689 &, 000 \\
\hline & Penguasaan Kosakata & 496 &, 082 &, 102 & 2,198 &, 002 \\
\hline & Struktur Kalimat & 464 & 117 & 320 & 3,108 &, 003 \\
\hline
\end{tabular}

a. Dependent Variable: Pemahaman Bacaan Teks Eksposisi Bahasa Inggris

1. Pengaruh penguasaan kosakata $\left(X_{1}\right)$ dan struktur kalimat $\left(X_{2}\right)$ secara bersama-sama terhadap pemahaman bacaan teks eksposisi bahasa Inggris (Y)

Hipotesis yang diuji:

$$
\begin{aligned}
& H_{0}: \beta_{y 1}=\beta_{y 2}=0 \\
& H_{1}: \beta_{y 1} \neq 0, \text { atau } \beta_{y 2} \neq 0
\end{aligned}
$$

Artinya: 
$\mathrm{H}_{0} \quad$ Tidak terdapat pengaruh penguasaan kosakata dan struktur kalimat secara bersama-sama terhadap pemahaman bacaan teks eksposisi bahasa Inggris

$\mathrm{H}_{1} \quad$ Terdapat pengaruh penguasaan kosakata dan struktur kalimat secara bersama-sama terhadap pemahaman bacaan teks eksposisi bahasa Inggris.

Dari Tabel 8 dapat dinyatakan bahwa terdapat pengaruh yang signifikan penguasaan kosakata dan struktur kalimat secara bersama-sama terhadap pemahaman bacaan teks eksposisi bahasa Inggris. Hal ini dibuktikan dengan perolehan nilai Sig. 0,003 ${ }^{\text {b }}<0,05$ dan $F_{\text {hitung }} 6,382$.

\section{Interpretasi Hasil Penelitian}

Tujuan dari penelitian ini adalah untuk mengetahui pengaruh dari penguasaan kosakata dan struktur kalimat secara bersama-sama terhadap pemahaman bacaan teks eksposisi bahasa Inggris siswa SMP Swasta di Jakarta Timur.

Tabe1 9. Penguasaan Kosa Kata dan Minat Baca

Model Summary
\begin{tabular}{|l|c|r|r|r|}
\hline Model & R & R Square & $\begin{array}{c}\text { Adjusted R } \\
\text { Square }\end{array}$ & $\begin{array}{c}\text { Std. Error of } \\
\text { the Estimate }\end{array}$ \\
\hline 1 &, $813^{\mathrm{a}}$ &, 660 &, 646 & 3,319 \\
\hline
\end{tabular}

a. Predictors: (Constant), Penguasaan Kosakata, Minat Baca

\section{Pengaruh Penguasaan Kosakata dan Struktur Kalimat secara bersama-sama terhadap Pemahaman Bacaan Teks Eksposisi Bahasa Inggris}

Dari deskripsi data setelah dilakukan analisis korelasi maka diperoleh koefisien korelasi sebesar 0,855 dan koefisien determinasi sebesar $73,1 \%$ dengan pengujian melalui program SPSS 22 . Terbukti bahwa koefisien korelasi tersebut signifikan. Sementara nilai Sig sebesar 0,003 dengan hasil $\mathrm{F}$ hitung sebesar 6,382 menunjukkan bahwa terdapat pengaruh penguasaan kosakata $\left(\mathrm{X}_{1}\right)$ dan struktur kalimat $\left(\mathrm{X}_{2}\right)$ secara bersama-sama terhadap pemahaman bacaan teks eksposisi bahasa Inggris (Y).

Sedangkan berdasarkan analisis regresi diperoleh persamaan garis $\hat{\mathrm{Y}}=1,461+0,496(\mathrm{Y})+0,496$ $\left(\mathrm{X}_{1}\right)+0,464\left(\mathrm{X}_{2}\right)$. Nilai konstanta sebesar 1,461 menunjukkan bahwa dengan penguasaan kosakata dan struktur kalimat yang paling rendah, akan sulit bagi siswa untuk menghasilkan suatu pemahaman bacaan teks eksposisi bahasa Inggris yang baik. Sementara, nilai koefisien sebesar 0,496 dan 0,464 menunjukkan terdapat pengaruh dari penguasaan kosakata $\left(\mathrm{X}_{1}\right)$ dan struktur kalimat $\left(\mathrm{X}_{2}\right)$ secara bersama-sama terhadap pemahaman bacaan teks eksposisi bahasa Inggris (Y). Angka koefisien regresi tersebut juga menunjukkan bahwa setiap ada kenaikan satu nilai penguasaan kosakata, maka akan terdapat kenaikan pemahaman bacaan teks eksposisi bahasa Inggris sebesar 0,496. Begitu pun setiap ada kenaikan satu nilai struktur kalimat, maka akan terdapat kenaikan pemahaman bacaan teks eksposisi bahasa Inggris sebesar 0,464. Setelah dilakukan pengujian linieritas gari regresi dengan menggunakan program SPSS 22 diperoleh bahwa garis regresi tersebut terbukti linier. Dari pengujian signifikansi koefisien regresi yang juga dilakukan dengan program aplikasi yang sama diperoleh bahwa koefisien regresi tersebut signifikan, yang berarti benar bahwa terdapat pengaruh yang signifikan dari penguasaan kosakata $\left(\mathrm{X}_{1}\right)$ dan struktur kalimat $\left(\mathrm{X}_{2}\right)$ secara bersama-sama terhadap pemahaman bacaan teks eksposisi bahasa Inggris (Y).

Berdasarkan hasil analisis data kuantitatif di atas, maka dapat disimpulkan bahwa terdapat pengaruh yang signifikan penguasaan kosakata dan struktur kalimat secara bersama-sama terhadap pemahaman bacaan teks eksposisi bahasa Inggris.

2. Pengaruh Penguasaan Kosakata terhadap Pemahaman Bacaan Teks Eksposisi Bahasa Inggris.

Dari pengujian hipotesis diperoleh bahwa nilai signifikansi (Sig) adalah 0,002 dan $t_{\text {hitung }}=2,198$ sedangkan $t_{\text {tabel }}=1,986$. Karena nilai Sig $<0,05$ dan $t_{\text {hitung }}>t_{\text {tabel }}$ maka $H_{0}$ ditolak dan $H_{1}$ diterima, yang berarti terdapat pengaruh yang signifikan antara penguasaan kosakata $\left(\mathrm{X}_{1}\right)$ terhadap pemahaman bacaan teks eksposisi bahasa Inggris (Y).

Pemahaman bacaan teks eksposisi merupakan sebuah pemahaman akan mampu menunjukkan pengetahuan dan kemampuannya menggunakan serta menjelaskan kembali informasi yang diperolehnya 
dari sebuah teks eksposisi. Sementara penguasaan kosakata merupakan kemampuan untuk menggunakan sebanyak mungkin kosakata yang terdapat dalam sebuah bahasa.

Berdasarkan hasil analisis data kuantitatif dan uraian di atas, maka dapat disimpulkan bahwa terdapat pengaruh yang signifikan penguasaan kosakata terhadap pemahaman bacaan teks eksposisi bahasa Inggris. 3. Pengaruh Struktur Kalimat terhadap Pemahaman Bacaan Teks Eksposisi Bahasa Inggris

Dari pengujian hipotesis bahwa diperoleh nilai signifikansi (Sig) adalah 0,003 dan $\mathrm{t}_{\text {hitung }}=3,108$ sedangkan $t_{\text {tabel }}=1,986$. Karena nilai Sig $<0,05$ dan $t_{\text {hitung }}>t_{\text {tabel }}$ maka $H_{0}$ ditolak dan $H_{1}$ diterima, yang berarti terdapat pengaruh yang signifikan antara Struktur kalimat $\left(\mathrm{X}_{2}\right)$ terhadap pemahaman bacaan teks eksposisi bahasa Inggris (Y).

Pemahaman bacaan teks eksposisi sebagaimana sudah diuraikan pada uraian sebelumnya merupakan sebuah pemahaman akan mampu menunjukkan pengetahuan dan kemampuannya menggunakan serta menjelaskan kembali informasi yang diperolehnya dari sebuah teks eksposisi. Sedangkan struktur kalimat adalah susunan kalimat yang disesuaikan dengan tujuan penulisan kalimat itu sendiri. Menurut Tarigan (2008, hal. 17) penyusunan struktur paragraf didasarkan pada dua hal. Pertama, berdasarkan berbagai kemungkinan posisi unsur kalimat. Kedua, berdasarkan berbagai kemungkinan posisi unsur kalimat dalam paragraf. Oleh karena itu penguasaan struktur paragraf berarti kemampuan memahami dan membentuk struktur paragraf yang saling melengkapi satu sama lainnya sehingga terbentuk sebuah teks yang baik, yaitu teks yang memiliki struktur kalimat yang dapat mengantarkan maksud penulis sehingga dipahami oleh pembaca. Berdasarkan hasil analisis data kuantitatif dan uraian teori di atas, maka peneliti mengambil kesimpulan bahwa struktur kalimat memberi pengaruh yang signifikan terhadap pemahaman bacaan teks eksposisi bahasa Inggris.

\section{Simpulan}

Terdapat pengaruh yang signifikan penguasaan kosakata dan struktur kalimat secara bersama-sama terhadap pemahaman bacaan teks eksposisi bahasa Inggris siswa. Hal ini dibuktikan dengan perolehan nilai $\operatorname{Sig}=0,003<0,05$ dan $F_{\text {hitung }}=6,382$. Terdapat pengaruh yang signifikan penguasaan kosakata terhadap pemahaman bacaan teks eksposisi bahasa Inggris siswa. Hal ini dibuktikan dengan perolehan nilai Sig= $0,002<0,05$ dan $t_{\text {hitung }}=2,198$. Terdapat pengaruh yang signifikan struktur kalimat terhadap pemahaman bacaan teks eksposisi bahasa Inggris siswa. Hal ini dibuktikan dengan perolehan nilai $\operatorname{Sig}=0,003<0,05$, dan oleh $\mathrm{t}_{\text {hitung }}=3,108$.

\section{Daftar Rujukan}

Allen, G. (2000). Intertextuality. Routledge. https://books.google.co.id/books?id=fYE71uQV68gC

Cameron, L. (2001). Teaching Languages to Young Learners. In Cambridge Language Teaching Library. Cambridge University Press. https://doi.org/10.1017/CBO9780511733109

Dykes, B. (2007). Grammar for everyone: Practical tools for learning and teaching grammar. ACER Press.

Faliyanti, E. (2015). The Correlation Between Students' Vocabulary Mastery and Their Interest in English Toward Reading Comprehension in Descriptive Text. PREMISE JOURNAL, 4(2), 68. https://doi.org/10.24127/pj.v4i2.301

Fitriani, R., \& Suendarti, M. (2021). Pengaruh Persepsi Atas Gaya Belajar Dan Penguasaan Kosakata Terhadap Pemahaman Bacaan Teks Recount. INFERENCE: Journal of English Language Teaching, 4(2), 120-129. https://journal.lppmunindra.ac.id/index.php/inference/article/view/6021

Harmer, D. (2020). Teacher inquiry. In E. H. Van Zee \& J. Minstrell (Ed.), Inquiring into Inquiry Learning and Teaching in Science (hal. 184-215). AAAS Publication.

Harmer, J. (2007). How to Teach English. Pearson Longman. https://books.google.co.id/books?id=0s_JZIuhHP8C

Johnson, D., \& Johnson, R. T. (2013). The impact of cooperative, competitive, and individualistic 
INFERENCE: Journal of English Language Teaching

Vol. 4, No. 3, December 2021 - March 2022

p-ISSN: 2615-8671

e-ISSN: 2615-868X

learning environments on achievement. In J. Hattie \& E. Anderman (Ed.), International handbook of student achievement (hal. 372-374). Routledge.

https://www.researchgate.net/publication/260596923_Johnson_D_W_Johnson_R_T_2013_The_imp act_of_cooperative_competitive_and_individualistic_learning_environments_on_achievement_In_J _Hattie_E_Anderman_Eds_International_handbook_of_student_achievement_372

Kartono, K. (2018). Pengaruh Kemampuan Membaca Cepat dan Sikap Berbahasa terhadap Kemampan Menulis Eksposisi Bahasa Inggris. Inference: Journal of English Language Teaching, 1(1).

https://journal.lppmunindra.ac.id/index.php/inference/article/view/3816

Longstreet, W. S., \& Shane, H. G. (1992). Curriculum for a New Millennium (1st ed.). Pearson.

Manullang, L., \& Supeno, S. (2020). The effects of vocabulary mastery and reading interest on EFL students' narrative writing skills. INFERENCE: Journal of English Language Teaching, 3(3), 200. https://doi.org/10.30998/inference.v3i3.5774

Novianti. (2019). Pengaruh minat baca dan penguasaan kosakata terhadap prestasi belajar bahasa Inggris. Inference: Journal of English Language Teaching2, 2(1).

https://journal.lppmunindra.ac.id/index.php/inference/article/view/5414

Porter, B. De, \& Hernacki, M. (2003). Quantum learning (A. Abdurrahman (penerj.)). PT Mizan Publika. https://books.google.com/books?id=6_Nx2_6T2cAC

Sugiyono. (2016). Metode penelitian kuantitatif, kualitatif,dan R\&D. CV. Alfabeta.

Sugiyono. (2017). Statistika untuk penelitian. CV. Alfabeta.

Tarigan, H. G. (2008). Menulis sebagai suatu keterampilan berbahasa. Angkasa.

Tarigan, H. G. (2011). Pengajaran Kosakata. Angkasa.

Thornbury, S. (2007). How to teach speaking. Longman.

Wiggins, G. (2014). How Good Is Good Enough? Educational Leadership, 7(4), 10-16. http://www.ascd.org/publications/educational-leadership/dec13/vol71/num04/How-Good-Is-GoodEnoughø.aspx 